Atmos. Chem. Phys., 13, 12537-12547, 2013

www.atmos-chem-phys.net/13/12537/2013/

doi:10.5194/acp-13-12537-2013

(c) Author(s) 2013. CC Attribution 3.0 License.

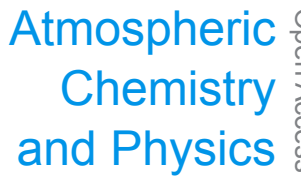

(c) (P)

\title{
Free-troposphere ozone and carbon monoxide over the North Atlantic for 2001-2011
}

\author{
A. Kumar ${ }^{1}$, S. Wu ${ }^{1,2}$, M. F. Weise ${ }^{1, *}$, R. Honrath ${ }^{1,2, \dagger}$, R. C. Owen ${ }^{3}$, D. Helmig ${ }^{4}$, L. Kramer ${ }^{2}$, M. Val Martin ${ }^{5}$, and \\ Q. $\mathbf{L i}^{6}$ \\ ${ }^{1}$ Department of Civil \& Environmental Engineering, Michigan Technological University, Houghton, Michigan, USA \\ ${ }^{2}$ Department of Geological and Mining Engineering and Sciences, Michigan Technological University, Houghton, Michigan, \\ USA \\ ${ }^{3}$ US EPA, Research Triangle Park, North Carolina, USA \\ ${ }^{4}$ Institute of Alpine and Arctic Research, University of Colorado at Boulder, Boulder, Colorado, USA \\ ${ }^{5}$ Department of Atmospheric Sciences, Colorado State University, Fort Collins, Colorado, USA \\ ${ }^{6}$ Department of Atmospheric \& Oceanic Sciences, University of California Los Angeles, Los Angeles, California, USA \\ *now at: ARCADIS, Novi, Michigan, USA \\ $\dagger$ deceased \\ Correspondence to: A. Kumar (adityak@mtu.edu)
}

Received: 14 May 2013 - Published in Atmos. Chem. Phys. Discuss.: 11 June 2013

Revised: 6 October 2013 - Accepted: 15 November 2013 - Published: 20 December 2013

\begin{abstract}
In situ measurements of carbon monoxide (CO) and ozone $\left(\mathrm{O}_{3}\right)$ at the Pico Mountain Observatory (PMO) located in the Azores, Portugal, are analyzed together with results from an atmospheric chemical transport model (GEOSChem) and satellite remote sensing data (AIRS (Atmospheric Infrared Sounder) for CO, and TES (Tropospheric Emission Spectrometer) for $\mathrm{O}_{3}$ ) to examine the evolution of freetroposphere $\mathrm{CO}$ and $\mathrm{O}_{3}$ over the North Atlantic for 20012011. GEOS-Chem captured the seasonal cycles for $\mathrm{CO}$ and $\mathrm{O}_{3}$ well but significantly underestimated the mixing ratios of CO, particularly in spring. Statistically significant (using a significance level of 0.05 ) decreasing trends were found for both $\mathrm{CO}$ and $\mathrm{O}_{3}$ based on harmonic regression analysis of the measurement data. The best estimates of the possible trends for $\mathrm{CO}$ and $\mathrm{O}_{3}$ measurements are $-0.31 \pm 0.30$ $(2-\sigma) \mathrm{ppbv} \mathrm{yr}^{-1}$ and $-0.21 \pm 0.11(2-\sigma) \mathrm{ppbv} \mathrm{yr}^{-1}$, respectively. Similar decreasing trends for both species were obtained with GEOS-Chem simulation results. The most important factor contributing to the decreases in $\mathrm{CO}$ and $\mathrm{O}_{3}$ at PMO over the past decade is the decline in anthropogenic emissions from North America, which more than compensate for the impacts from increasing Asian emissions. It is likely that climate change in the past decade has also affected the intercontinental transport of $\mathrm{O}_{3}$.
\end{abstract}

\section{Introduction}

Carbon monoxide $(\mathrm{CO})$ and ozone $\left(\mathrm{O}_{3}\right)$ are important atmospheric pollutants in the troposphere. The major sources of atmospheric $\mathrm{CO}$ include incomplete combustion of fossil fuels and biomass burning (Duncan et al., 2007; Holloway et al., 2000; Khalil and Rasmussen, 1994; Seinfeld and Pandis, 2006). CO is also formed through the oxidation of volatile organic compounds (VOCs) by the hydroxyl radical $(\mathrm{OH})$. $\mathrm{O}_{3}$ is formed in the troposphere through photochemical reactions in the presence of $\mathrm{O}_{3}$ precursors, which include the nitrogen oxides $\left(\mathrm{NO}_{\mathrm{x}} \equiv \mathrm{NO}+\mathrm{NO}_{2}\right), \mathrm{CO}$ and VOCs. The dominant loss pathway for tropospheric $\mathrm{O}_{3}$ is photolysis followed by reaction with water vapor.

Atmospheric transport across the North Atlantic Ocean carries air pollutants from the continent of North America towards Europe. The atmospheric lifetime of $\mathrm{CO}$ ranges from weeks to months (Duncan et al., 2007), and the lifetime for $\mathrm{O}_{3}$ varies from days to months in the troposphere (Law, 2010; Wang et al., 1998). These relatively long lifetimes enable these species to undergo intercontinental transport. Thus, changes in emissions from source regions (such as North America) can have significant implications for atmospheric composition in downwind regions such as the North Atlantic or Europe. Li et al. (2002) found that $20 \%$ 


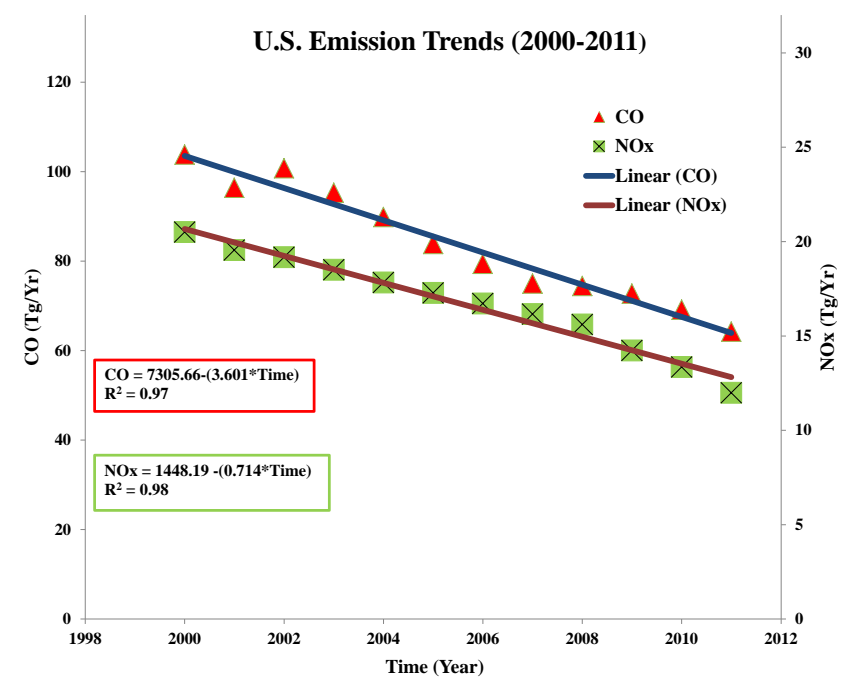

Fig. 1. US anthropogenic emissions (in $\mathrm{Tg} \mathrm{r}^{-1}$ ) for $\mathrm{CO}$ and $\mathrm{NO}_{\mathrm{x}}$ from 2000 to 2011 (data available at: http://www.epa.gov/ttnchie1/ trends/).

of summer violations of $\mathrm{O}_{3}$ air quality standards in Europe would not have occurred in the absence of North American anthropogenic emissions.

Increases in anthropogenic emissions of $\mathrm{NO}_{\mathrm{x}}, \mathrm{CO}$ and VOCs have led to increases in free-tropospheric $\mathrm{O}_{3}$ since pre-industrial times (Wang and Jacob, 1998) although several studies have reported divergent trends of tropospheric $\mathrm{O}_{3}$ over different regions of the Northern Hemisphere (Brunke et al., 1998; Cooper et al., 2010; Fusco and Logan, 2003; Guicherit and Roemer, 2000; Jaffe et al., 2003; Lee et al., 1998; Oltmans et al., 2006; Parrish et al., 2010, 2013). Over the past decade, emissions of $\mathrm{O}_{3}$ precursors have declined significantly in North America and Europe (Hudman et al., 2009), while those in Asia have increased (Vingarzan, 2004). Figure 1 shows the trends of anthropogenic emissions of $\mathrm{CO}$ and $\mathrm{NO}_{\mathrm{x}}$ in the United States (US) from 2000 to 2011. US sources account for approximately $80 \%$ of anthropogenic emissions from North America (Wang et al., 2009). These changes in emissions are expected to influence the freetroposphere $\mathrm{CO}$ and $\mathrm{O}_{3}$ concentrations over the North Atlantic. The Pico Mountain Observatory located in the central North Atlantic region (details provided in the next section) is a unique site that can be used to measure species relevant to long-range transport and thereby examine the direct continental outflow from North America. In this study, we combine 10-year in situ measurements of $\mathrm{CO}$ and $\mathrm{O}_{3}$ at this station with results from a chemical transport model (the GEOS-Chem chemical transport model) as well as satellite data to examine the seasonal variation and long-term trends in free-tropospheric $\mathrm{CO}$ and $\mathrm{O}_{3}$ over the North Atlantic for the past decade.

\section{Measurement data}

\subsection{Measurements at the Pico Mountain Observatory}

The Pico Mountain Observatory (PMO, formerly called PICO-NARE) is located on the summit of Pico Mountain on Pico Island in the Azores, Portugal $\left(38^{\circ} 28^{\prime} \mathrm{N}, 28^{\circ} 24^{\prime} \mathrm{W}\right)$, at an altitude of $2225 \mathrm{~m}$ (Honrath et al., 2004). This station is well above the Marine Boundary Layer (MBL) during summertime and ideal for examining the atmospheric composition of the lower free troposphere (FT). The island population is low (around 15000) and is concentrated near sea level, which results in the site having negligible anthropogenic influence on the free-troposphere composition, although upslope flows have been found to occur, resulting in the transport of low-altitude air to the mountaintop (Kleissl et al., 2007). However, the occurrence of such flow is not very frequent and even when it occurs it was found that the air did not originate from the surface (Kleissl et al., 2007).

The station is also frequently impacted by export of North American pollution during summertime and outflow from Arctic and sub-Arctic regions, resulting in transport of biomass burning emissions from Canada, Alaska and Siberia (Honrath et al., 2004; Val Martin et al., 2008b). Val Martin et al. (2006) reported that North American boreal wildfires contributed significantly to enhancements in $\mathrm{CO}$ and $\mathrm{O}_{3}$ background mixing ratios during the summer of 2004. Honrath et al. (2004) also observed frequent enhancements in CO levels above the marine background levels during the summertime in 2001-2003 which they attributed to North American pollution outflow or long-range transport of biomass burning emissions. High levels of both $\mathrm{CO}$ and $\mathrm{O}_{3}$ were observed during the periods of biomass burning.

$\mathrm{CO}$ and $\mathrm{O}_{3}$ have been measured at PMO using instruments described by Honrath et al. (2004). We use hourly CO data covering 2001-2010 and $\mathrm{O}_{3}$ data spanning 2001-2011 with most of the available data spanning May-September. Considering the diurnal variations of $\mathrm{CO}$ and $\mathrm{O}_{3}$, we have applied a $24 \mathrm{~h}$ filter to avoid unexpected bias - i.e., only days with full $24 \mathrm{~h}$ data availability were used to calculate the daily average mixing ratios of $\mathrm{CO}$ and $\mathrm{O}_{3}$. The application of this filter resulted in the inclusion of approximately $76 \%(87 \%)$ of the total $\mathrm{CO}\left(\mathrm{O}_{3}\right)$ measurements in the final analysis.

\subsection{Satellite data}

\subsubsection{AIRS/AQUA data for CO}

The Atmospheric Infrared Sounder (AIRS) was launched onboard the AQUA satellite on 4 May 2002. It is a polarorbiting nadir-viewing thermal IR sounder with cloud clearing capability and retrieves $\mathrm{CO}$ at 4.7 microns with $70 \%$ daily global coverage $-100 \%$ between $45^{\circ}$ and $80^{\circ}$ longitude (McMillan et al., 2005; Yurganov et al., 2008). We use AIRS level 3 version 5 monthly data obtained from 
Giovanni, Goddard Earth Sciences Data and Information Services Center (GES DISC). Data are available at http://disc. sci.gsfc.nasa.gov/giovanni\#instances (Acker and Leptoukh, 2007). Level 3 datasets have undergone rigorous processing and are available with no subsequent processing required. As done in prior studies, AIRS measurements with more than 0.5 degrees of freedom (Fisher et al., 2010) were included in the analysis. Previous comparisons of AIRS with in situ measurements reveal a positive bias of $\sim 10 \%$ in the Northern Hemisphere (Fisher et al., 2010; Kopacz et al., 2010). Retrievals for the area matching the same horizontal grid as GEOS-Chem over PMO $\left(32.5^{\circ}\right.$ to $27.5^{\circ} \mathrm{W}$ and $36^{\circ}$ to $\left.40^{\circ} \mathrm{N}\right)$ centered at $802 \mathrm{hPa}$ (roughly $2.2 \mathrm{~km}$, the same elevation as PMO) are used in this study. Since both the measurement data at PMO and GEOS-Chem use both day and night values, day and night retrievals are used for AIRS as well.

\subsubsection{TES/AURA data for $\mathrm{O}_{3}$}

The Tropospheric Emission Spectrometer (TES) was launched in July 2004 aboard the Earth Observing System (EOS) Aura satellite. Data were obtained from Giovanni online data system, developed and maintained by the NASA GES DISC as mentioned above (Sect. 2.2.1). TES is nadir viewing in a polar-orbiting Sun-synchronous orbit on the same track as AIRS/AQUA with a local crossing time of 01:45 and 13:45 (Zhang et al., 2010). We use available data for the period covering 2005-2010 in this study. The data for 2008-2009 were not available. The level three data used were pre-processed and all negative values were filtered out. Previous comparisons with in situ measurements show that TES has a positive bias of $5.3 \mathrm{ppbv}$ for $\mathrm{O}_{3}$ at $500 \mathrm{hPa}$ (Zhang et al., 2010).

\section{Model description and simulations}

GEOS-Chem is a global three-dimensional model of tropospheric chemistry driven by assimilated meteorological observations from the Goddard Earth Observing System (GEOS) of the NASA Global Modeling Assimilation Office (Bey et al., 2001; Evans and Jacob, 2005; Fairlie et al., 2007; Huang et al., 2013; Johnson et al., 2010; Martin et al., 2002; Park et al., 2004; Wu et al., 2007; Yu et al., 2010). The model has fully coupled $\mathrm{O}_{3}-\mathrm{NO}_{\mathrm{x}}-\mathrm{VOC}$ aerosol chemistry and has been extensively evaluated and applied to a wide range of research topics related to atmospheric chemistry and air quality (e.g., Duncan et al., 2007; Evans and Jacob, 2005; González Abad et al., 2011; Hudman et al., 2007, 2008; Martin et al., 2002; Park et al., 2004;Wu et al., 2008a, b, 2012). There have been different versions of the GEOS meteorology, including GEOS-3, GEOS-4 and GEOS-5, with each spanning different periods. Emission inventories in GEOS-Chem cover various sources, including anthropogenic, biomass burning, biofuel and biogenic emissions. Anthropogenic emissions fol- low the Emissions Database for Global Atmospheric Research (EDGAR) global inventory (Olivier and Berdowski, 2001) and are updated with regional inventories, including the US EPA National Emissions Inventory (EPA/NEI05 and EPA/NEI99), the Environment Canada National Pollutant Release (CAC) Inventory, the European Monitoring and Evaluation Programme (EMEP) inventory, the Streets emission inventory in Asia (Streets et al., 2003, 2006; Zhang et al., 2009) and the Big Bend Regional Aerosol and Visibility Observational (BRAVO) study emissions inventory for Mexico and some neighboring US states. The biomass burning emissions follow either the Global Fire Emissions Database (GFED) v2 (1997-2008) (van der Werf et al., 2006) or GFEDv3 (1997-2010) monthly inventories (van der Werf et al., 2010) and biogenic VOC emissions are taken from the Model of Emissions of Gases and Aerosols from Nature (MEGAN) global inventory. Emissions from other natural sources (e.g., lightning, volcanoes) are also included. For chemistry, either the Kinetic PreProcessor (KPP) (Eller et al., 2009; Sandu and Sander, 2006) or the Sparse-Matrix Vectorized Gear 2 (SMVGEAR 2) (Eller et al., 2009) chemistry solver can be used. The Linearized Ozone (LINOZ) mechanism (McLinden et al., 2000) is used for the stratospheretroposphere exchange of $\mathrm{O}_{3}$.

In addition to the standard full chemistry simulations with GEOS-Chem, we also carry out special tagged simulations (tagged $\mathrm{CO}$ and tagged $\mathrm{O}_{3}$ simulations) to better identify the contributions to $\mathrm{CO}$ and $\mathrm{O}_{3}$ at $\mathrm{PMO}$ from various source regions. A brief description of the simulations used in this study and the archived data is provided in the following sections.

\subsection{Full chemistry simulations used}

The full chemistry simulations using the standard version of GEOS-Chem with normal emissions are referred to here as FCNE simulations. We used the $4^{\circ} \times 5^{\circ}$ (latitude $\times$ longitude) horizontal resolution and a one-year spinup for all the FCNE simulations. GEOS-4 meteorological fields were used for 2001-2004, whereas those from GEOS5 covered the period from 2005 onwards. Regional emission inventories for anthropogenic (fossil fuel and biofuel) emissions were used over Canada (CAC inventory), Mexico (BRAVO), Asia (Streets), USA (NEI2005 and EPA/NEI99) and Europe (EMEP). The other regions were covered by the EDGAR global anthropogenic emissions inventory. Biogenic VOCs in the model include emissions of isoprene, methyl butenol and seven monoterpene compounds following the MEGAN scheme (Guenther et al., 2006). For biomass burning emissions, the GFEDv2 monthly inventory was used (as the updated GFEDv3 inventory was not available with the model version (v8-03-01) used). Model-simulated $\mathrm{CO}$ and $\mathrm{O}_{3}$ mixing ratios for the grid box covering PMO were archived with a $4 \mathrm{~h}$ temporal resolution. These $4 \mathrm{~h}$ 
instantaneous mixing ratios were used to compute the daily averages for both the species.

Table 1 summarizes the anthropogenic and biomass burning $\mathrm{CO}$ emissions in GEOS-Chem for various regions of the Northern Hemisphere for 2001-2009. The emission inventories indicate significant declines in anthropogenic $\mathrm{CO}$ for North America and Europe but increases from Asia during this time period.

A sensitivity run was also performed to assess the impact of North American fossil fuel combustion on $\mathrm{CO}$ and $\mathrm{O}_{3}$ at PMO by excluding those emissions. This run had no fossil fuel emissions for the region covering the US, Canada and Mexico $\left(15^{\circ} \mathrm{N}\right.$ to $88^{\circ} \mathrm{N}$ (latitude) and $50^{\circ} \mathrm{W}$ to $165^{\circ} \mathrm{W}$ (longitude)).

\subsection{Tagged CO simulation}

The GEOS-Chem tagged CO simulation was used to determine the contribution to $\mathrm{CO}$ mixing ratios at $\mathrm{PMO}$ from various geographical regions (e.g., Asia, North America) and sources (e.g., biomass burning, biofuels). It is one of the several offline simulations included in GEOS-Chem and consists of source/region-specific $\mathrm{CO}$ tracers. The $\mathrm{CO}$ sources accounted for include fossil fuels, biofuels, biomass burning, anthropogenic and biogenic VOCs. A detailed description can be found in Duncan et al. (2007). The reaction of $\mathrm{CO}$ with $\mathrm{OH}$ is the only sink considered. We used v9-0102 of the model with the $4^{\circ} \times 5^{\circ}$ (latitude $\times$ longitude) horizontal resolution. For this simulation, emission inventories included to account for anthropogenic $\mathrm{CO}$ production were the global EDGAR inventory, CAC inventory over Canada, BRAVO over Mexico, EPA/NEI99 over North America, Streets over southeastern Asia and the RETRO (for global anthropogenic VOCs) inventory. For biomass burning emissions, the monthly GFEDv3 emissions (available with the version used) were used. The $\mathrm{OH}$ concentrations used were those archived from a separate full chemistry simulation. Restart files for the tagged CO simulation were generated by an eleven-month (February 2000-December 2000) spin-up (with zero initial concentrations for all the tracers) for the period 2001-2004 (using GEOS-4) until steady-state concentrations were reached. For the run with GEOS-5 (20052010), a one-year spin-up (January 2004-December 2004) was used. The data archived consists of the time series of 4-hourly instantaneous values of all the $\mathrm{CO}$ tracers at PMO from 2001 to 2010. These values were used to obtain the daily average for each $\mathrm{CO}$ tracer.

\subsection{Tagged $\mathrm{O}_{3}$ simulation}

The tagged $\mathrm{O}_{3}$ simulation was used to attribute the $\mathrm{O}_{3}$ mixing ratios at PMO to $\mathrm{O}_{3}$ production from various regions. It uses chemical production/loss rates of $\mathrm{O}_{3}$ archived from the FCNE simulation. We used version 09-01-02 of GEOSChem (horizontal resolution $4^{\circ} \times 5^{\circ}$ (latitude $\times$ longitude))

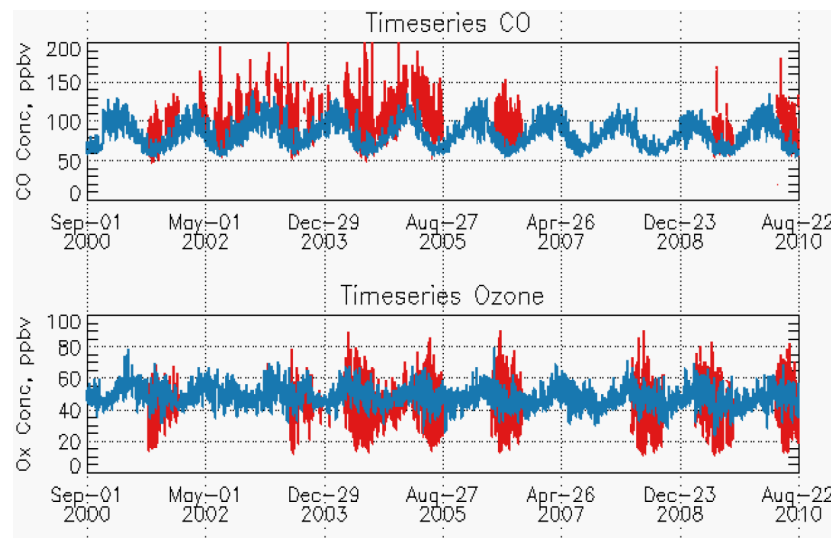

Fig. 2. Time series of $\mathrm{CO}$ (top) and $\mathrm{O}_{3}$ (bottom) from September 2000-August 2010. The observations are shown in red and GEOS-Chem output is shown in blue.

for this simulation, and the same version was also used to archive the $\mathrm{O}_{3}$ production/loss rates from 2000 to 2011 . Restart files were generated in the same manner as for the tagged CO simulation. The time series of 4-hourly instantaneous values of all the tracers was archived from 2001 to 2011 for the location and altitude corresponding to PMO. The daily averages for all tracers were computed using these 4-hourly instantaneous values.

\section{GEOS-Chem model evaluation}

GEOS-Chem output for $\mathrm{CO}$ and $\mathrm{O}_{3}$ mixing ratios was compared with the in situ measurement data for the two species at PMO as well as satellite retrievals from AIRS/AQUA (for $\mathrm{CO}$ ) and TES/AURA (for $\mathrm{O}_{3}$ ). Figure 2 shows the time series of $24 \mathrm{~h}$ average $\mathrm{O}_{3}$ and $\mathrm{CO}$ mixing ratios at PMO from September 2000 to August 2010 along with the $24 \mathrm{~h}$ averages computed from GEOS-Chem time series output for this period. For CO, GEOS-Chem was found to underestimate the observations, with the magnitude during summer being $24.7 \pm 5.2 \mathrm{ppbv}(1-\sigma)$. The significant underestimate of $\mathrm{CO}$ by GEOS-Chem possibly reflects some low biases in the $\mathrm{CO}$ emission inventories used in the model. The model underestimates of $\mathrm{CO}$ have also been reported by previous studies (Bey et al., 2001; Duncan and Logan, 2008; Duncan et al., 2007; Fiore et al., 2002; Heald et al., 2003; Kopacz et al., 2010; Val Martin et al., 2008a; Zhang et al., 2008). For O $\mathrm{O}_{3}$, the GEOS-Chem performance was much better. The model was $6.7 \pm 2.6$ ppbv higher and showed the least agreement in winter and best agreement in summer and fall.

The seasonal variation of $\mathrm{CO}$ and $\mathrm{O}_{3}$ at $\mathrm{PMO}$ was further examined in Fig. 3 with box plots for GEOS-Chem model simulations ( $24 \mathrm{~h}$ averages) compared with ground-based in situ measurements and satellite data. The data used in Fig. 3 cover the period of September 2004 to August 2005 as this period has the best data availability for the measurements. 


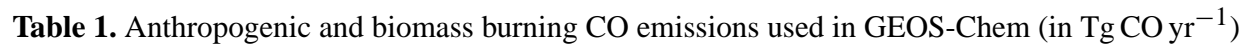

\begin{tabular}{c|cccc|cc}
\hline & \multicolumn{3}{|c|}{ Anthropogenic } & \multicolumn{2}{c}{ Biomass burning } \\
\hline Year & Northern Hemisphere & North America & Europe & Asia & Northern Hemisphere & North America \\
\hline 2001 & 436.5 & 97.3 & 45.1 & 245.9 & 202.6 & 8.7 \\
2002 & 447.9 & 99.9 & 42.8 & 256.0 & 230.9 & 21.3 \\
2003 & 460.3 & 95.5 & 41.6 & 272.9 & 246.5 & 33.9 \\
2004 & 461.1 & 90.6 & 41.6 & 278.1 & 201.0 & 23.2 \\
2005 & 460.1 & 86.3 & 40.0 & 281.8 & 216.0 & 20.7 \\
2006 & 460.7 & 83.0 & 38.2 & 286.2 & 180.9 & 15.5 \\
2007 & 455.9 & 83.0 & 35.4 & 286.2 & 219.6 & 15.3 \\
2008 & 457.2 & 83.2 & 35.6 & 287.0 & 180.9 & 13.8 \\
2009 & 455.9 & 83.0 & 35.4 & 286.2 & 180.0 & 13.8 \\
\hline
\end{tabular}

Table 2. $\mathrm{CO}$ and $\mathrm{O}_{3}$ trends obtained for PMO observations and GEOS-Chem output.

\begin{tabular}{lcccc}
\hline \multirow{2}{*}{ Species } & \multicolumn{2}{c}{ Trend $\left(\mathrm{ppbv} \mathrm{yr}^{-1}\right)^{*}$} & \multicolumn{2}{c}{$p$ value } \\
& Observations & GEOS-Chem & Observations & GEOS-Chem \\
\hline $\mathrm{CO}$ & $-0.31 \pm 0.30$ & $-0.34 \pm 0.08$ & 0.04 & $<0.001$ \\
$\mathrm{O}_{3}$ & $-0.21 \pm 0.11$ & $-0.53 \pm 0.04$ & $<0.001$ & $<0.001$ \\
\hline
\end{tabular}

* Uncertainties are in the $2-\sigma(95 \%)$ interval.

Both Figs. 2 and 3 show that the seasonal variations associated with $\mathrm{CO}$ and $\mathrm{O}_{3}$ are well captured by GEOS-Chem. Both species show maxima in the springtime and minima in the summertime with consistency between the model results and measurement data. Similar seasonal variations have also been reported for these species at other remote sites such as Mace Head (Derwent et al., 1998) and mountaintop stations such as Mt. Cimone (Bonasoni et al., 2000) and for CO in a previous study at the PMO (Val Martin et al., 2008a). The AIRS data further confirm the model underestimate of $\mathrm{CO}$ which is particularly large during late spring-early summer. We also compared model results with observational data on the interannual variability of $\mathrm{O}_{3}$ at PMO (Fig. 4). The period of May-August was chosen for best data coverage, and average $\mathrm{O}_{3}$ mixing ratio for this period was calculated for each year. Some years without sufficient observational data coverage were excluded from the comparison. We find that besides the period of 2004-2006, the interannual variability of $\mathrm{O}_{3}$ at PMO reflected from the GEOS-Chem model results generally agrees well with the observational data (Fig. 4).

\section{Long-term trends of $\mathrm{CO}$ and $\mathrm{O}_{3}$ at $\mathrm{PMO}$}

\subsection{Trend analysis methodology}

Two-sided parametric hypothesis testing (null hypothesis of no trend and alternate hypothesis of non-zero trend) was used to analyze the trends in $\mathrm{CO}$ and $\mathrm{O}_{3}$ mixing ratios at PMO for 2001-2011. We employed a multiple regression model that is similar to the additive model of a time series and con- tains sinusoidal functions to represent the characteristic seasonal variations of both $\mathrm{CO}$ and $\mathrm{O}_{3}$. Following Helsel and Hirsch (2002), we express the model for daily average values of $\mathrm{CO}$ or $\mathrm{O}_{3}$ as

$C_{t}=a_{0}+a_{1} t+a_{2} \sin \left(\frac{2 \pi t}{365}\right)+a_{3} \cos \left(\frac{2 \pi t}{365}\right)+\varepsilon_{t}$,

where $C_{t}$ is the daily average mixing ratio of the species at a time $t$ (days since a reference time); $a_{0}, a_{1}, a_{2}$, and $a_{3}$ are regression coefficients; and $\varepsilon_{t}$ is residual from the model.

The sinusoidal functions use a time period of one year to reflect the seasonal variations of $\mathrm{CO}$ and $\mathrm{O}_{3}$. The linear term $\left(\mathrm{a}_{1} \mathrm{t}\right)$ with time was used to represent the long-term trend in $\mathrm{CO}$ or $\mathrm{O}_{3}$.

For all datasets consisting of daily averages, a five-day centered simple moving average scheme was applied to the data before fitting the regression model. Coefficients in the regression equation were determined by the least squares method, and the statistical significance of the $t$ statistic corresponding to the slope term was examined by comparing the probability of observing a $t$ statistic of same or greater magnitude with the null hypothesis being true ( $p$ value) with the significance level $\alpha$ (0.05 used for this study).

\subsection{Trends of $\mathrm{CO}$ and $\mathrm{O}_{3}$ at PMO}

The regression model in Eq. (1) was applied to the time series of $\mathrm{CO}$ and $\mathrm{O}_{3}$ (for both the in situ measurements and GEOS-Chem FCNE simulation output) at PMO. Table 2 lists the trends for both the measurement data and GEOSChem output along with the associated $p$ values. Figure 5 

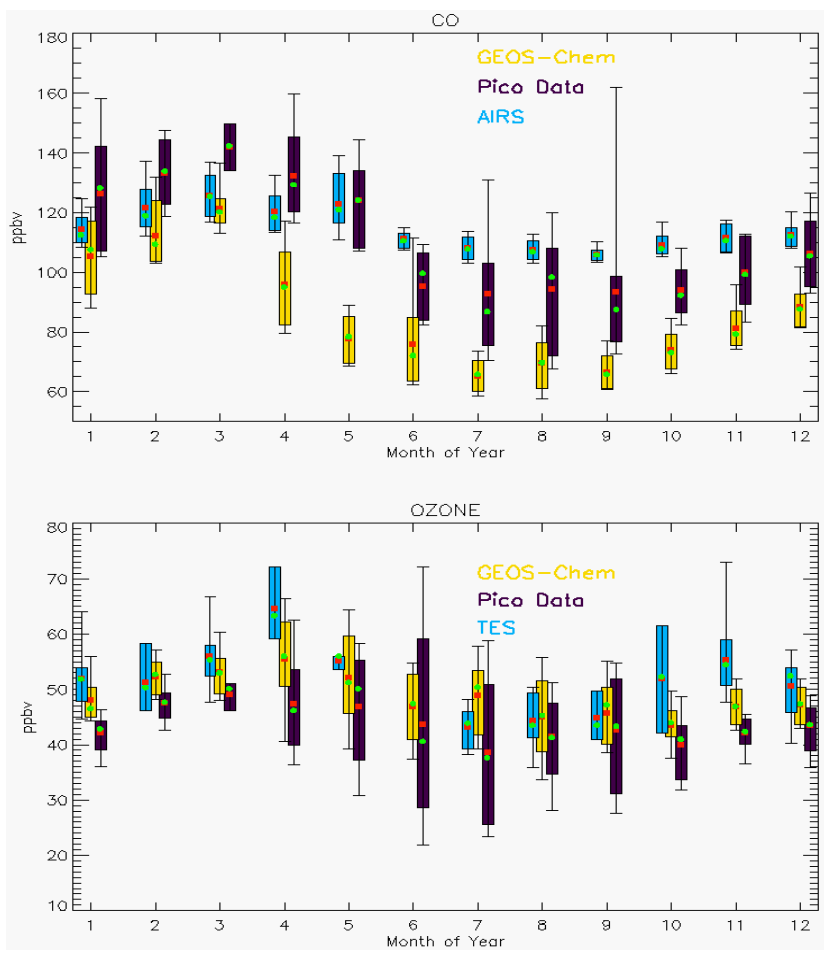

Fig. 3. Seasonal variation of $\mathrm{CO}$ (top) and $\mathrm{O}_{3}$ (bottom) at $\mathrm{PMO}$ (September 2004-August 2005) as indicated by GEOS-Chem model simulations (yellow), in situ measurements (dark brown) and satellite observations (AIRS for $\mathrm{CO}$ and TES for $\mathrm{O}_{3}$ ) (light blue). The thick (thin) bars represent the $67 \%(90 \%)$ confidence intervals. The mean and median are represented with red and green dots, respectively.The statistics are based on daily $(24 \mathrm{~h})$ averages.

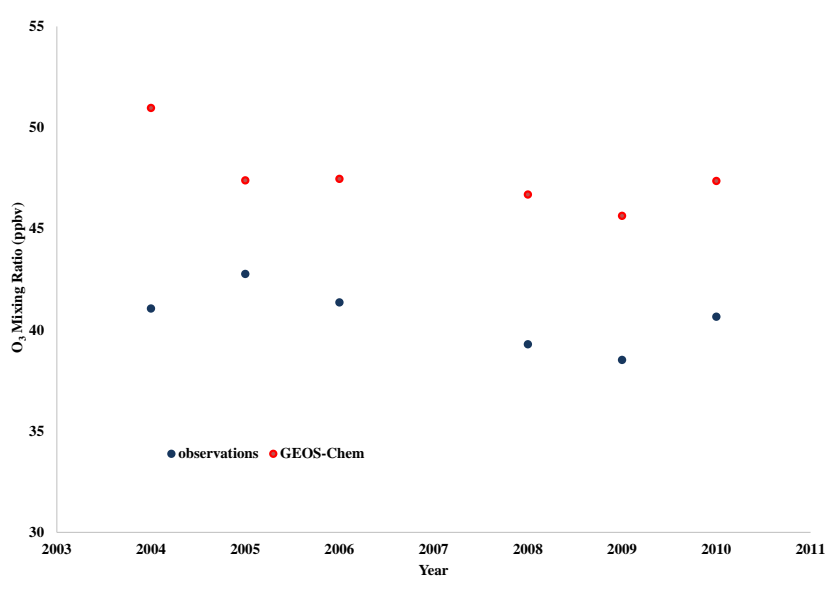

Fig. 4. Seasonal (May-August) average $\mathrm{O}_{3}$ for 2004-2010 from observations (blue) and GEOS-Chem simulation (red).

shows the regression fits for the $\mathrm{CO}$ and $\mathrm{O}_{3}$ measurements, and Figure 6 contains the fits for the modeled (GEOS-Chem FCNE simulation) $\mathrm{CO}$ and $\mathrm{O}_{3}$. The observations show statistically significant decreasing trends for both the species over the study period, with $\mathrm{CO}$ showing a decrease of
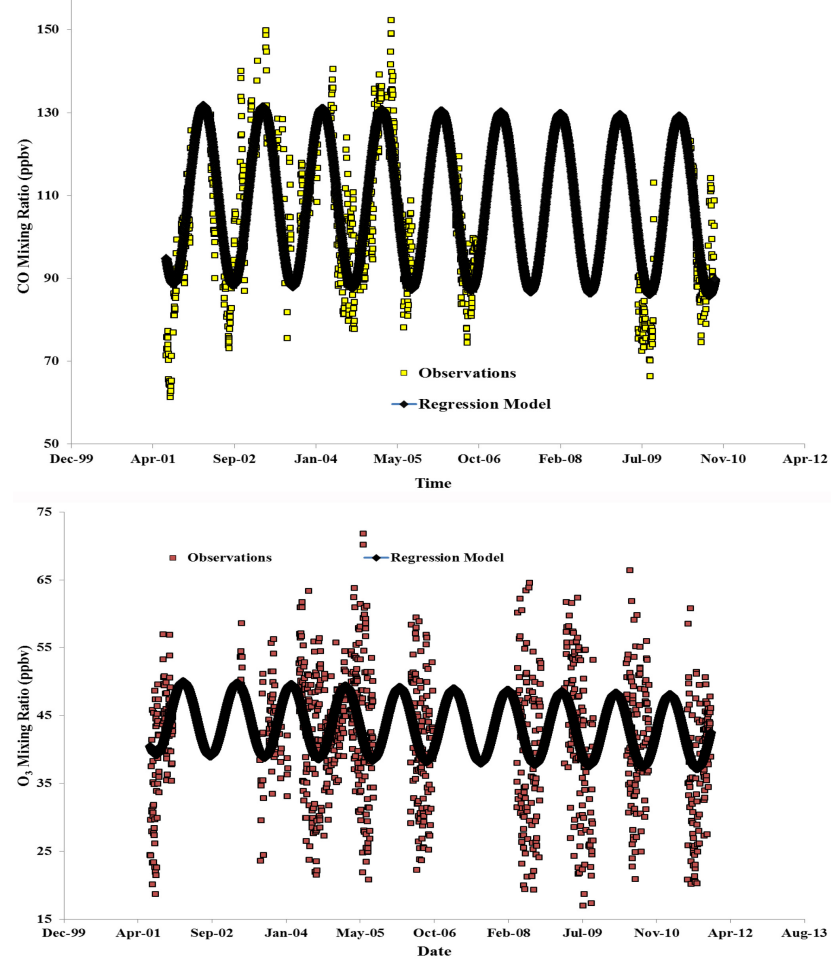

Fig. 5. Regression model fit to the PMO observations for CO (top) and $\mathrm{O}_{3}$ (bottom).

$-0.31 \pm 0.30(2-\sigma) \operatorname{ppbv~yr}^{-1}(p$ value $=0.04)$ and $\mathrm{O}_{3}$ decreasing by $-0.21 \pm 0.11(2-\sigma) \operatorname{ppbv~yr}^{-1}(p$ value $<0.001)$. GEOS-Chem also shows statistically significant decreasing trends for both $\mathrm{CO}\left(-0.34 \pm 0.08(2-\sigma) \mathrm{ppbv} \mathrm{yr}^{-1}\right.$, $p$ value $<0.001)$ and $\mathrm{O}_{3}\left(-0.53 \pm 0.04(2-\sigma) \mathrm{ppbv} \mathrm{yr}^{-1}\right.$, $p$ value $<0.001$ ).

These decreasing trends are in agreement with those obtained from observation data at other stations in the North Atlantic such as Tudor Hill, Bermuda (TH), and Mace Head, Ireland $(\mathrm{MH})$ (data available at http://ds.data.jma. go.jp/gmd/wdcgg/cgi-bin/wdcgg/catalogue.cgi). For TH, the harmonic regression analysis of $\mathrm{O}_{3}$ mixing ratios from 2003 to 2011 yields a statistically significant decreasing trend $(p$ value $<0.001)$ of $1.1 \pm 0.11(2-\sigma) \mathrm{ppbv} \mathrm{yr}^{-1}$, whereas $\mathrm{CO}$ at $\mathrm{MH}$ (2001-2011) shows a statistically significant decreasing trend $\left(-1.4 \pm 0.20(2-\sigma) \mathrm{ppbv} \mathrm{yr}^{-1}\right.$, $p$ value $<0.001)$ as well. However, measurements at Izana, Tenerife (IT) (data available at http://ds.data.jma.go.jp/ gmd/wdcgg/cgi-bin/wdcgg/catalogue.cgi), show an increasing trend of $0.10 \pm 0.07(2-\sigma) \mathrm{ppbv} \mathrm{yr}^{-1}$ for $\mathrm{O}_{3}$ over the study period. This opposite trend at IT could indicate the fact that it is further south and less affected by the continental outflow from North America. Previous studies such as Lelieveld et al. (2004) and Derwent et al. (2007) have reported upward trends in $\mathrm{O}_{3}$ over the North Atlantic for the periods 1977 2002 and 1987-2007, respectively. The discrepancy appears 


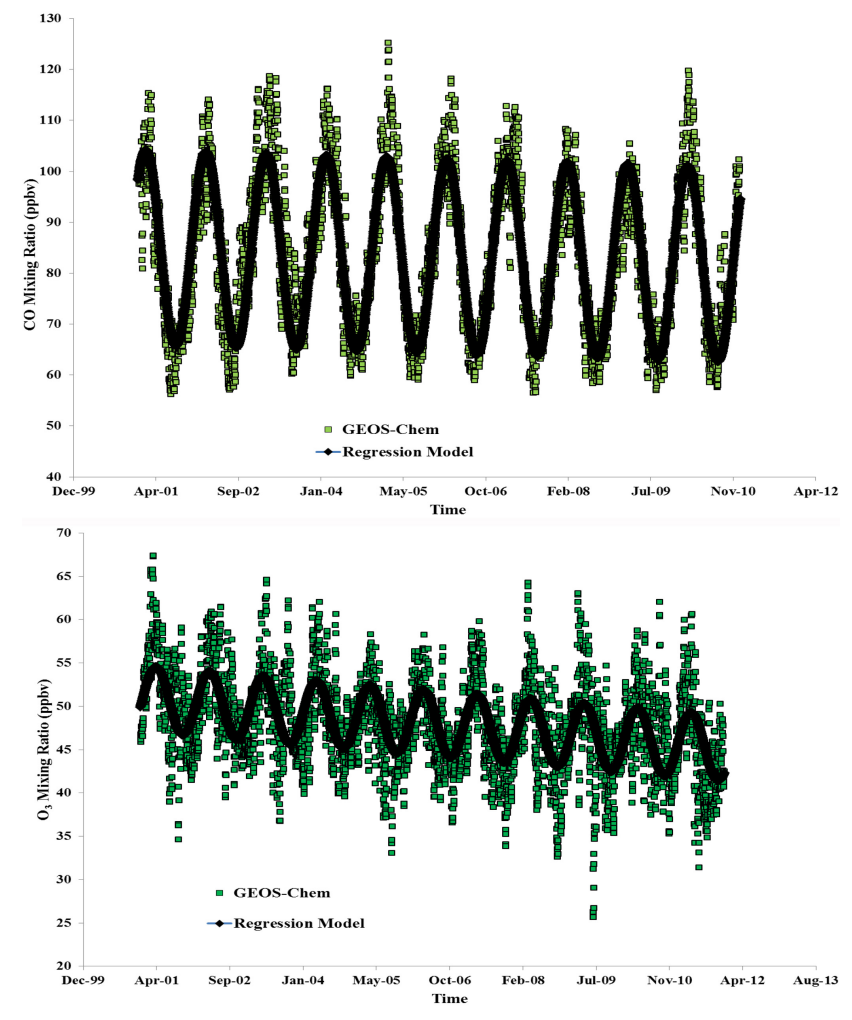

Fig. 6. Regression model fit to the GEOS-Chem simulation results for $\mathrm{CO}$ (top) and $\mathrm{O}_{3}$ (bottom) at $\mathrm{PMO}$.

largely due to the different time frame used in these studies. This factor is exemplified by the different trends observed for $\mathrm{O}_{3}$ at $\mathrm{TH}$ (increasing trend of $0.70 \pm 0.10(2-\sigma) \mathrm{ppbv} \mathrm{yr}^{-1}$, $p$ value < 0.001 ) for the earlier decade of $1988-1998$ as compared to the decreasing trend for 2003-2011.

One of the major factors that could lead to a decrease in $\mathrm{CO}$ and $\mathrm{O}_{3}$ mixing ratios over the North Atlantic is the decline in anthropogenic emissions from North America (of which $80 \%$ of emissions are from the US) in the past decade. The trends for US anthropogenic emissions of $\mathrm{CO}$ and $\mathrm{NO}_{\mathrm{x}}$ are shown in Fig. 1. In order to investigate this hypothesis, we first carried out sensitivity runs by turning off North American fossil fuel emissions in the model (Sect. 3.1) to derive the contribution of North American anthropogenic emissions to $\mathrm{CO}$ and $\mathrm{O}_{3}$ at $\mathrm{PMO}$. Our results show that the anthropogenic emissions from North America enhance the annual means of $\mathrm{CO}$ and $\mathrm{O}_{3}$ at $\mathrm{PMO}$ by 8.6 and $4.0 \mathrm{ppbv} \mathrm{yr}^{-1}$, respectively (Table 3). Also, Figure 1 shows that the US CO emissions have declined by about $1 / 3$, from around $105 \mathrm{Tg}$ in 2000 to $70 \mathrm{Tg}$ in 2011. Assuming a linear correspondence between the US emissions and their contribution to $\mathrm{CO}$ mixing ratios at PMO, this would amount to a decrease of approximately $2.9 \mathrm{ppbv}$ in the $\mathrm{CO}$ at the station (over the past decade). This change is similar to that obtained from the harmonic regression analysis of $\mathrm{CO}$ measurements at PMO, suggesting that the observed possible decline in the $\mathrm{CO}$ at the station cor-
Table 3. Contribution to $\mathrm{CO}$ and $\mathrm{O}_{3}$ at $\mathrm{PMO}$ from North American fossil fuel emissions simulated by the GEOS-Chem model (means for every season from fall 2000 to summer 2010).

\begin{tabular}{lcc}
\hline Season & $\mathrm{CO}(\mathrm{ppbv})$ & $\mathrm{O}_{3}(\mathrm{ppbv})$ \\
\hline Fall & 5.7 & 4.4 \\
Winter & 12.7 & 2.3 \\
Spring & 11.0 & 4.5 \\
Summer & 4.9 & 4.9 \\
Annual & 8.6 & 4.0 \\
\hline
\end{tabular}

Table 4. Trends in contributions to $\mathrm{CO}$ at $\mathrm{PMO}$ from various regions and sources ${ }^{\mathrm{a}}$.

\begin{tabular}{lrc}
\hline CO source $^{\mathrm{b}}$ & Trend $\left(\mathrm{ppbv} \mathrm{yr}^{-1}\right)^{\mathrm{c}}$ & $p$ value \\
\hline CO (ff USA) & $-0.27 \pm 0.05$ & $<0.001$ \\
CO (ff Europe) & $-0.004 \pm 0.03$ & 0.39 \\
CO (ff Asia) & $+0.35 \pm 0.03$ & $<0.001$ \\
CO (bb North America) & $-0.03 \pm 0.02$ & 0.004 \\
CO (bb Europe) & $-0.30 \pm 0.03$ & $<0.001$ \\
CO (bb Asia) & $+0.05 \pm 0.01$ & $<0.001$ \\
\hline
\end{tabular}

\footnotetext{
a Results based on GEOS-Chem tagged CO simulation results;

$\mathrm{b} \mathrm{ff}=$ emissions from fossil fuel combustion; $\mathrm{bb}=$ emissions from biomass burning;

${ }^{c}$ Uncertainties are in the $2-\sigma(95 \%)$ interval.
}

relates particularly well with the US emission declines. For $\mathrm{CO}$, the largest contribution from North American emissions was found in the winter and spring, which reflects stronger atmospheric transport and longer chemical lifetimes of $\mathrm{CO}$ (due to low levels of $\mathrm{OH}$ ) during those seasons, as previously noted by Val Martin et al. (2008a). In contrast, for $\mathrm{O}_{3}$, the least North American contribution was found during winter, reflecting the $\mathrm{NO}_{\mathrm{x}}$-saturated regime where $\mathrm{O}_{3}$ production is more sensitive to the photochemically generated hydrogen oxide radicals $\left(\mathrm{HO}_{\mathrm{x}}\right)$ (Jacob et al., 1995; Kleinman et al., 1995).

In order to better understand and quantify the effects associated with the decreases in North American emissions, we also carried out tagged $\mathrm{CO}$ and $\mathrm{O}_{3}$ simulations with the GEOS-Chem model. Results of the trend analysis for the tagged $\mathrm{CO}$ simulation are summarized in Table 4 . The contribution of $\mathrm{CO}$ produced from anthropogenic fossil fuel emissions in the US to CO at PMO shows a statistically significant $(p$ value $<0.001)$ decrease over the study period. The contribution of biomass burning emissions in Europe also shows a statistically significant $(p$ value $<0.001)$ decrease. On the other hand, contribution of fossil fuel emissions in Asia shows a statistically significant $(p$ value $<0.001)$ increase. These results indicate that reductions in $\mathrm{CO}$ from North America and Europe could be the primary reasons for the possible decrease in $\mathrm{CO}$ at $\mathrm{PMO}$, which outweigh the effects of increasing $\mathrm{CO}$ from Asia in the past decade. 
Table 5. Trends in contributions to $\mathrm{O}_{3}$ at $\mathrm{PMO}$ from various regions and sources ${ }^{1}$.

\begin{tabular}{lll}
\hline $\mathrm{O}_{3}$ source $^{2}$ & Trend $\left(\mathrm{ppbv} \mathrm{yr}^{-1}\right)^{*}$ & $p$ value \\
\hline $\mathrm{O}_{3}$ (produced over the USA) & $-0.18 \pm 0.03$ & $<0.001$ \\
$\mathrm{O}_{3}$ (produced in the NA BL) & $-0.57 \pm 0.02$ & $<0.001$ \\
$\mathrm{O}_{3}$ (produced in the Asian BL) & $-0.12 \pm 0.004$ & $<0.001$ \\
$\mathrm{O}_{3}$ (produced in the European BL) & $-0.09 \pm 0.003$ & $<0.001$ \\
$\mathrm{O}_{3}$ (produced in the NAtl BL) & $-0.51 \pm 0.02$ & $<0.001$ \\
$\mathrm{O}_{3}$ (produced in the UT) & $+3.13 \pm 0.07$ & $<0.001$ \\
$\mathrm{O}_{3}$ (produced in the MT) & $-2.19 \pm 0.05$ & $<0.001$ \\
\hline
\end{tabular}

${ }^{\text {a }}$ Results based on GEOS-Chem tagged $\mathrm{O}_{3}$ simulation results;

b NA: North America; BL: boundary layer; NAtl: North Atlantic; UT: upper troposphere; MT: middle troposphere;

${ }^{\mathrm{c}}$ Uncertainties are in the 2- $\sigma(95 \%)$ interval.

Table 5 summarizes the results of the statistical analysis for the tagged $\mathrm{O}_{3}$ simulation. Statistically significant ( $p$ value $<0.001$ ) decreasing trends are obtained for the contributions to $\mathrm{O}_{3}$ at $\mathrm{PMO}$ from $\mathrm{O}_{3}$ production in the boundary layer over various regions, including North America, Europe and Asia. The contribution of $\mathrm{O}_{3}$ production in the middle troposphere (MT) (boundary layer top $-350 \mathrm{hPa}$ ) also shows a decreasing trend ( $p$ value $<0.001$ ) over the study period. On the other hand, an increasing trend ( $p$ value $<0.001)$ was identified for the contribution from $\mathrm{O}_{3}$ produced in the upper troposphere (UT) $(350 \mathrm{hPa}$ - tropopause).

The decreasing trends for contributions to $\mathrm{O}_{3}$ at PMO from North America and Europe are consistent with the declines in anthropogenic $\mathrm{O}_{3}$ precursor emissions in these regions. On the other hand, the decrease in the contribution of $\mathrm{O}_{3}$ produced in Asia (where anthropogenic precursor emissions have been increasing) may reflect the impacts from climate change in the past decade. Except for regions with strong emissions of $\mathrm{O}_{3}$ precursors, climate change generally decreases surface $\mathrm{O}_{3}$ due to enhanced $\mathrm{O}_{3}$ destruction associated with higher water vapor concentration in the atmosphere (e.g., Johnson et al., 1999; Wu et al., 2008b). With reduced chemical lifetime of $\mathrm{O}_{3}$, this effect is particularly important for remote regions and the long-range transport of atmospheric $\mathrm{O}_{3}$. Analysis of the atmospheric water vapor concentrations in the past decade shows significant increases (up to $20 \%$ ) over the North Atlantic for the study period which contributes to a shorter $\mathrm{O}_{3}$ lifetime during transport. The increase in the contribution of $\mathrm{O}_{3}$ produced in the UT could be due to an increase in the $\mathrm{NO}_{\mathrm{x}}$ production from lightning. Harmonic regression analysis of global lightning flashes archived from GEOS-Chem for 2001-2011 shows a statistically significant increase over this period, which points to an increase in the $\mathrm{NO}_{\mathrm{x}}$ produced. The uppertroposphere $\mathrm{O}_{3}$ is highly sensitive to $\mathrm{NO}_{\mathrm{x}}$ emissions from lightning, with the $\mathrm{O}_{3}$ production efficiency (referenced to $\mathrm{NO}_{\mathrm{x}}$ emissions) being about six times higher than that for $\mathrm{NO}_{\mathrm{x}}$ emissions in surface air (Wu et al., 2007).
The statistically significant decreasing trend for the contribution of $\mathrm{O}_{3}$ production in the North Atlantic largely reflects the decline in the anthropogenic emissions from North America. When comparing the contributions from various regions (North America, Europe and Asia) in Table 5, we can see that the reductions in anthropogenic emissions of $\mathrm{O}_{3}$ precursors are the most important factor contributing to the possible decrease in $\mathrm{O}_{3}$ mixing ratios observed at PMO.

\section{Conclusions and discussion}

This study analyzes in situ measurements of $\mathrm{CO}$ and $\mathrm{O}_{3}$ at the Pico mountaintop observatory and output from GEOSChem model simulations to determine the possible trends in $\mathrm{CO}$ and $\mathrm{O}_{3}$ over the North Atlantic region for the past decade. The GEOS-Chem model performance is also evaluated by comparing simulation results against measurements at PMO and satellite observations. The model reproduces the seasonal variations of $\mathrm{CO}$ and $\mathrm{O}_{3}$ at PMO reasonably well although it significantly underestimates $\mathrm{CO}$ at this remote site.

Sensitivity studies show that North American fossil fuel emissions contribute to $\mathrm{CO}$ and $\mathrm{O}_{3}$ at the Pico site by 8.6 and $4.0 \mathrm{ppbv}$, respectively. This contribution to the $\mathrm{CO}$ mixing ratios is greatest during winter and spring, reflecting the longer CO lifetime and stronger transport during those seasons. In contrast, the contribution to $\mathrm{O}_{3}$ is found to be smallest during winter, reflecting the low $\mathrm{O}_{3}$ production and low sensitivity to $\mathrm{NO}_{\mathrm{x}}$ emissions during wintertime.

Harmonic regression analysis of the observed $\mathrm{CO}$ and $\mathrm{O}_{3}$ mixing ratios at $\mathrm{PMO}$ for 2001-2011 shows statistically significant decreases for both species. The best estimates of the possible trends for the $\mathrm{CO}$ and $\mathrm{O}_{3}$ measurements are $-0.31 \pm 0.30(2-\sigma)$ ppbv yr $^{-1}$ and $-0.21 \pm 0.11$ $(2-\sigma) \mathrm{ppbv} \mathrm{yr}^{-1}$, respectively. GEOS-Chem model simulations for the past decade also yield decreasing trends for $\mathrm{CO}$ and $\mathrm{O}_{3}$ at $\mathrm{PMO}$. We conducted tagged simulations for $\mathrm{CO}$ and $\mathrm{O}_{3}$, respectively, with GEOS-Chem to attribute these decreases. Contribution to $\mathrm{CO}$ at PMO from fossil fuel emissions in the United States shows a statistically significant decreasing trend $\left(-0.27 \pm 0.05(2-\sigma) \mathrm{ppbv} \mathrm{yr}^{-1}\right)$, while the contribution from fossil fuel emissions in Asia shows a statistically significant increasing trend $(+0.35 \pm 0.03$

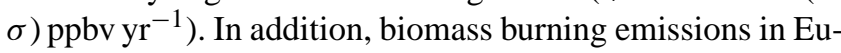
rope show statistically significant decreasing contribution $\left(-0.3 \pm 0.03(2-\sigma) \mathrm{ppbv} \mathrm{yr}^{-1}\right)$. These results indicate that, even though the increasing $\mathrm{CO}$ emissions from Asia in the past decade have led to increasing enhancement in $\mathrm{CO}$ over the North Atlantic, the decreases in CO from North America and Europe more than compensate for these increases and result in an overall decreasing trend in $\mathrm{CO}$ at PMO. The changes in $\mathrm{O}_{3}$ at $\mathrm{PMO}$ are attributed to $\mathrm{O}_{3}$ production in various regions (e.g., North America, North Atlantic, Europe and Asia) through tagged $\mathrm{O}_{3}$ simulations with the GEOSChem model. Contributions from $\mathrm{O}_{3}$ produced in the lower 
and middle troposphere also show statistically significant decreasing trends. The decreases in the contribution of $\mathrm{O}_{3}$ from North America and Europe as well as the North Atlantic are consistent with the decreases in anthropogenic emissions of $\mathrm{O}_{3}$ precursors in North America and Europe in the past decade. While the anthropogenic emissions in Asia have increased in the past decade, the decreasing trend for contribution to $\mathrm{PMO} \mathrm{O}_{3}$ from Asia possibly reflects the impacts of climate change which can decrease the atmospheric lifetime of $\mathrm{O}_{3}$ and therefore suppress its long-range transport. Further study is required to examine the potential impacts of climate change on intercontinental transport. Overall, the emission reduction of $\mathrm{O}_{3}$ precursors in North America in the past decade is the most important factor contributing to the possible decreasing trends of $\mathrm{CO}$ and $\mathrm{O}_{3}$ at $\mathrm{PMO}$.

Acknowledgements. This research and the operation of the Pico Mountain Observatory have been supported by several agencies, including the NSF Atmospheric Chemistry program, the NOAA Office of Global Programs, and the Regional Government of the Azores, and through funding from the UK National Environment Research Council for the BORTAS project. We thank Pei Hou at Michigan Tech for helping on processing the atmospheric humidity data. This publication was made possible by USEPA STAR grant (83518901). Its contents are solely the responsibility of the grantee and do not necessarily represent the official views of the USEPA. Further, USEPA does not endorse the purchase of any commercial products or services mentioned in the publication.

Edited by: S. Matthiesen

\section{References}

Acker, J. G. and Leptoukh, G.: Online analysis enhances use of NASA Earth science data, Eos, Trans. Am. Geophys. Union, 88, 14-17, 2007.

Bey, I., Jacob, D. J., Yantosca, R. M., Logan, J. A., Field, B. D., Fiore, A. M., Li, Q., Liu, H. Y., Mickley, L. J., and Schultz, M. G.: Global modeling of tropospheric chemistry with assimilated meteorology: Model description and evaluation, J. Geophys. Res., 106, 023073-023096, 2001.

Bonasoni, P., Stohl, A., Cristofanelli, P., Calzolari, F., Colombo, T., and Evangelisti, F.: Background ozone variations at Mt. Cimone station, Atmos. Environ., 34, 5183-5189, 2000.

Brunke, E., Meyer, N., Lathrop, J., Johnson, B., Shadwick, D., Cuevas, E., Schmidlin, F., Tarasick, D., Claude, H., and Kerr, J.: Trends of ozone in the troposphere, Geophys. Res. Lett., 25, 139-142, 1998.

Cooper, O. R., Parrish, D. D., Stohl, A., Trainer, M., Nédélec, P., Thouret, V., Cammas, J. P., Oltmans, S. J., Johnson, B. J., and Tarasick, D.: Increasing springtime ozone mixing ratios in the free troposphere over western North America, Nature, 463, 344 348, doi:10.1038/nature08708, 2010.

Derwent, R. G., Simmonds, P. G., Seuring, S., and Dimmer, C.: Observation and interpretation of seasonal cycles in the surface concentrations of ozone and carbon monoxide at Mace Head,
Ireland, from 1990 to 1994, Atmos. Environ., 32, 145-157, doi:10.1016/S1352-2310(1097)00338-00335, 1998.

Derwent, R. G., Simmonds, P. G., Manning, A. J., and Spain, T. G.: Trends over a 20-year period from 1987 to 2007 in surface ozone at the atmospheric research station, Mace Head, Ireland, Atmos. Environ., 41, 9091-9098, 2007.

Duncan, B. N. and Logan, J. A.: Model analysis of the factors regulating the trends and variability of carbon monoxide between 1988 and 1997, Atmos. Chem. Phys., 8, 7389-7403, doi:10.5194/acp-7388-7389-2008, 2008.

Duncan, B. N., Logan, J. A., Bey, I., Megretskaia, I. A., Yantosca, R. M., Novelli, P. C., Jones, N. B., and Rinsland, C. P.: Global budget of CO, 1988-1997: Source estimates and validation with a global model, J. Geophys. Res., 112, D22301, doi:10.21029/22007JD008459, 2007.

Eller, P., Singh, K., Sandu, A., Bowman, K., Henze, D. K., and Lee, M.: Implementation and evaluation of an array of chemical solvers in the Global Chemical Transport Model GEOSChem, Geosci. Model Dev., 2, 89-96, doi:10.5194/gmd-2-892009, 2009.

Evans, M. J. and Jacob, D. J.: Impact of new laboratory studies of $\mathrm{N}_{2} \mathrm{O}_{5}$ hydrolysis on global model budgets of tropospheric nitrogen oxides, ozone, and OH, Geophys. Res. Lett., 32, L09813, doi:10.01029/02005GL022469, 2005.

Fairlie, T. D., Jacob, D. J., and Park, R. J.: The impact of transpacific transport of mineral dust in the United States, Atmos. Environ. 41, 1251-1266, 2007.

Fiore, A. M., Jacob, D. J., Bey, I., Yantosca, R. M., Field, B. D., Fusco, A. C., and Wilkinson, J. G.: Background ozone over the United States in summer: Origin, trend, and contribution to pollution episodes, J. Geophys. Res., 107, doi:10.1029/2001JD000982, 2002.

Fisher, J. A., Jacob, D. J., Purdy, M. T., Kopacz, M., Le Sager, P., Carouge, C., Holmes, C. D., Yantosca, R. M., Batchelor, R. L., Strong, K., Diskin, G. S., Fuelberg, H. E., Holloway, J. S., Hyer, E. J., McMillan, W. W., Warner, J., Streets, D. G., Zhang, Q., Wang, Y., and Wu, S.: Source attribution and interannual variability of Arctic pollution in spring constrained by aircraft (ARCTAS, ARCPAC) and satellite (AIRS) observations of carbon monoxide, Atmos. Chem. Phys., 10, 977-996, doi:10.5194/acp10-977-2010, 2010.

Fusco, A. C. and Logan, J. A.: Analysis of 1970-1995 trends in tropospheric ozone at Northern Hemisphere midlatitudes with the GEOS-CHEM model, J. Geophys. Res. Atmos., 108, ACH4ACH1, doi:10.1029/2002JD002742, 2003.

González Abad, G., Allen, N., Bernath, P., Boone, C., McLeod, S., Manney, G., Toon, G., Carouge, C., Wang, Y., and Wu, S.: Ethane, ethyne and carbon monoxide concentrations in the upper troposphere and lower stratosphere from ACE and GEOSChem: a comparison study, Atmos. Chem. Phys., 11, 9927-9941, doi:10.5194/acp-11-9927-2011, 2011.

Guenther, A., Karl, T., Harley, P., Wiedinmyer, C., Palmer, P. I., and Geron, C.: Estimates of global terrestrial isoprene emissions using MEGAN (Model of Emissions of Gases and Aerosols from Nature), Atmos. Chem. Phys., 6, 3181-3210, doi:10.5194/acp3186-3181-2006, 2006.

Guicherit, R., and Roemer, M.: Tropospheric ozone trends, Chemos.-Global Change Sci., 2, 167-183, 2000. 
Heald, C. L., Jacob, D. J., Fiore, A. M., Emmons, L. K., Gille, J. C., Deeter, M. N., Warner, J., Edwards, D. P., Crawford, J. H., and Hamlin, A. J.: Asian outflow and trans-Pacific transport of carbon monoxide and ozone pollution: An integrated satellite, aircraft, and model perspective, J. Geophys. Res. Atmos., 108, 4804, doi:10.1029/2003JD003507, 2003.

Helsel, D. R. and Hirsch, R. M.: Statistical methods in water resources, US Geological survey, Reston, VA, 2002.

Holloway, T., Hiram Levy, I., and Kasibhatla, P.: Global distribution of carbon monoxide, J. Geophys. Res., 105, 12123-12112, 2000.

Honrath, R. E., Owen, R. C., Val Martin, M., Reid, J. S., Lapina, K., Fialho, P., Dziobak, M. P., Kleissl, J., and Westphal, D. L.: Regional and hemispheric impacts of anthropogenic and biomass burning emissions on summertime $\mathrm{CO}$ and $\mathrm{O} 3$ in the North Atlantic lower free troposphere, J. Geophys. Res.-Atmos., 109, D24310, doi:10.1029/2004JD005147, 2004.

Huang, Y., Wu, S., Dubey, M. K., and French, N. H. F.: Impact of aging mechanism on model simulated carbonaceous aerosols, Atmos. Chem. Phys., 13, 6329-6343, doi:10.5194/acp-13-63292013, 2013.

Hudman, R. C., Jacob, D. J., Turquety, S., Leibensperger, E. M., Murray, L. T., Wu, S., Gilliland, A., Avery, M., Bertram, T. H., and Brune, W.: Surface and lightning sources of nitrogen oxides over the United States: Magnitudes, chemical evolution, and outflow, J. Geophys. Res. Atmos., 112, D12S05, doi:10.1029/2006JD007912, 2007.

Hudman, R. C., Murray, L. T., Jacob, D. J., Millet, D., Turquety, S., Wu, S., Blake, D., Goldstein, A., Holloway, J., and Sachse, G.: Biogenic versus anthropogenic sources of CO in the United States, Geophys. Res. Lett., 35, L04801, doi:10.1029/2007GL032393, 2008.

Hudman, R. C., Murray, L. T., Jacob, D. J., Turquety, S., Wu, S., Millet, D. B., Avery, M., Goldstein, A. H., and Holloway, J.: North American influence on tropospheric ozone and the effects of recent emission reductions: Constraints from ICARTT observations, J. Geophys. Res. Atmos., 114, D07302, doi:10.1029/2008JD010126, 2009.

Jacob, D. J., Horowitz, L. W., Munger, J. W., Heikes, B. G., Dickerson, R. R., Artz, R. S., and Keene, W. C.: Seasonal transition from NOx-to hydrocarbon-limited conditions for ozone production over the eastern United States in September, J. Geophys. Res. Atmos., 100, 9315-9324, 1995.

Jaffe, D., Price, H., Parrish, D., Goldstein, A., and Harris, J.: Increasing background ozone during spring on the west coast of North America, Geophys. Res. Lett., 30, 1613, doi:10.1029/2003GL017024, 2003.

Johnson, C. E., Collins, W. J., Stevenson, D. S., and Derwent, R. G.: Relative roles of climate and emissions changes on future tropospheric oxidant concentrations, J. Geophys. Res. Atmos., 104, 18631-18645, 1999.

Johnson, M. S., Meskhidze, N., Solmon, F., Gassó, S., Chuang, P. Y., Gaiero, D. M., Yantosca, R. M., Wu, S., Wang, Y., and Carouge, C.: Modeling dust and soluble iron deposition to the South Atlantic Ocean, J. Geophys. Res. Atmos., 115, D15202, doi:10.1029/2009JD013311, 2010.

Khalil, M. A. K. and Rasmussen, R. A.: Global decrease in atmospheric carbon monoxide, Nature, 370, 639-641, 1994.

Kleinman, L., Lee, Y. N., Springston, S. R., Lee, J. H., Nunnermacker, L., Weinstein-Lloyd, J., Zhou, X., and Newman, L.: Per- oxy radical concentration and ozone formation rate at a rural site in the southeastern United States, J. Geophys. Res., 100, 7263$7273,1995$.

Kleissl, J., Honrath, R. E., Dziobak, M. P., Tanner, D., Martin, M. V., Owen, R. C., and Helmig, D.: Occurrence of upslope flows at the Pico mountaintop observatory: A case study of orographic flows on a small, volcanic island, J. Geophys. Res., 112, D10S35, doi:10.1029/2006JD007565, 2007.

Kopacz, M., Jacob, D. J., Fisher, J. A., Logan, J. A., Zhang, L., Megretskaia, I. A., Yantosca, R. M., Singh, K., Henze, D. K., Burrows, J. P., Buchwitz, M., Khlystova, I., McMillan, W. W., Gille, J. C., Edwards, D. P., Eldering, A., Thouret, V., and Nedelec, P.: Global estimates of CO sources with high resolution by adjoint inversion of multiple satellite datasets (MOPITT, AIRS, SCIAMACHY, TES), Atmos. Chem. Phys., 10, 855-876, doi:10.5194/acp-10-855-2010, 2010.

Law, K.: More ozone over North America, Nature, 463, 307-308, 2010.

Lee, S. H., Akimoto, H., Nakane, H., Kurnosenko, S., and Kinjo, Y.: Lower tropospheric ozone trend observed in 1989-1997 at Okinawa, Japan, Geophys. Res. Lett., 25, 1637-1640, 1998.

Lelieveld, J., Van Aardenne, J., Fischer, H., De Reus, M., Williams, J., and Winkler, P. Increasing ozone over the Atlantic Ocean, Science, 304, 1483-1487, 2004.

Li, Q., Jacob, D. J., Bey, I., Palmer, P. I., Duncan, B. N., Field, B. D., Martin, R. V., Fiore, A. M., Yantosca, R. M., Parrish, D. D., Simmonds, P. G., and Oltmans, S. J.: Transatlantic transport of pollution and its effects on surface ozone in Europe and North America, J. Geophys. Res., 107, 4166, doi:10.1029/2001JD001422, 2002.

Martin, R. V., Chance, K., Jacob, D. J., Kurosu, T. P., Spurr, R. J. D., Bucsela, E., Gleason, J. F., Palmer, P. I., Bey, I., Fiore, A. M., Li, Q., Yantosca, R. M., and Koelemeijer, R. B. A.: An improved retrieval of tropospheric nitrogen dioxide from GOME, J. Geophys. Res. Atmos., 107, 4437-4456, doi:10.1029/2001JD001027, 2002.

McLinden, C. A., Olsen, S. C., Hannegan, B., Wild, O., Prather, M. J., and Sundet, J.: Stratospheric ozone in 3-D models: A simple chemistry and the cross-tropopause flux, J. Geophys. Res.Atmos., 105, 14653-14665, doi:10.11029/12000JD900124, 2000.

McMillan, W. W., Barnet, C., Strow, L., Chahine, M. T., McCourt, M. L., Warner, J. X., Novelli, P. C., Korontzi, S., Maddy, E. S., and Datta, S.: Daily global maps of carbon monoxide from NASA's Atmospheric Infrared Sounder, Geophys. Res. Lett., 32, L11801, doi:10.11029/12004GL021821, 2005.

Olivier, J. G. J. and Berdowski, J. J. M.: Global emission sources and sinks, in The Climate System, edited by: Berdowski, J., Guicherit, R., and Heij, B. J., 33-77, Swets \& Zeitlinger, Lisse, The Netherlands, 2001.

Oltmans, S. J., Lefohn, A. S., Harris, J. M., Galbally, I., Scheel, H. E., Bodeker, G., Brunke, E., Claude, H., Tarasick, D., Johnson, B. J., Simmonds, P., Shadwick, D., Anlauf, K., Hayden, K., Schmidlin, F., Fujimoto, T., Akagi, K., Meyer, C., Nichol, S., Davies, J., Redondas, A., and Cuevasa, E.: Long-term changes in tropospheric ozone, Atmos. Environ., 40, 3156-3173, 2006.

Park, R. J., Jacob, D. J., Field, B. D., Yantosca, R. M., and Chin, M.: Natural and transboundary pollution influences on sulfate-nitrate-ammonium aerosols in the United States: Im- 
plications for policy, J. Geophys. Res. Atmos., 109, D15204, doi:10.1029/2003JD004473, 2004.

Parrish, D. D., Aikin, K. C., Oltmans, S. J., Johnson, B. J., Ives, M., and Sweeny, C.: Impact of transported background ozone inflow on summertime air quality in a California ozone exceedance area, Atmos. Chem. Phys., 10, 10093-10109, doi:10.5194/acp10-10093-2010, 2010.

Parrish, D. D., Law, K. S., Staehelin, J., Derwent, R. G., Cooper, O. R., Tanimoto, H., Volz-Thomas, A., Gilge, S., Scheel, H. E., and Steinbacher, M.: Lower tropospheric ozone at northern midlatitudes: Changing seasonal cycle, Geophys. Res. Lett., 40, 16311636, doi:10.1002/grl.50303, 2013.

Sandu, A. and Sander, R.: Technical note: Simulating chemical systems in Fortran90 and Matlab with the Kinetic PreProcessor KPP-2.1, Atmos. Chem. Phys., 6, 187-195, doi:10.5194/acp-6187-2006, 2006.

Seinfeld, J. H. and Pandis, S. N.: Atmospheric Chemistry and Physics: From Air Pollution to Climate Change, Atmospheric Chemistry and Physics, John Wiley \& Sons, New York, 1326, 2006.

Streets, D. G., Bond, T. C., Carmichael, G. R., Fernandes, S. D., Fu, Q., He, D., Klimont, Z., Nelson, S. M., Tsai, N. Y., Wang, M. Q., Woo, J.-H., and Yarber, K. F.: An inventory of gaseous and primary aerosol emissions in Asia in the year 2000, J. Geophys. Res., 108, 8809, doi:10.1029/2002JD003093, 2003.

Streets, D. G., Zhang, Q., Wang, L., He, K., Hao, J., Wu, Y., Tang, Y., and Carmichael, G. R.: Revisiting China's CO emissions after the Transport and Chemical Evolution over the Pacific (TRACE-P) mission: Synthesis of inventories, atmospheric modeling, and observations, J. Geophys. Res., 111, D14306, doi:10.11029/12006JD007118, 2006.

Val Martin, M., Honrath, R. E., Owen, R. C., Pfister, G., Fialho, P., and Barata, F.: Significant enhancements of nitrogen oxides, black carbon, and ozone in the North Atlantic lower free troposphere resulting from North American boreal wildfires, J. Geophys. Res, 111, D23S60, doi:10.1029/2006JD007530, 2006

Val Martin, M., Honrath, R. E., Owen, R. C., and Li, Q. B.: Seasonal variation of nitrogen oxides in the central North Atlantic lower free troposphere, J. Geophys. Res. Atmos., 113, D17307, doi:10.1029/2007JD009688, 2008a

Val Martin, M., Honrath, R. E., Owen, R. C., and Lapina, K.: Largescale impacts of anthropogenic pollution and boreal wildfires on the nitrogen oxides over the central North Atlantic region, J. Geophys. Res., 113, D17308, doi:10.11029/12007JD009689, 2008b. van der Werf, G. R., Randerson, J. T., Giglio, L., Collatz, G. J., Kasibhatla, P. S., and Arellano Jr., A. F.: Interannual variability in global biomass burning emissions from 1997 to 2004, Atmos. Chem. Phys., 6, 3423-3441, doi:10.5194/acp-6-3423-2006, 2006.

van der Werf, G. R., Randerson, J. T., Giglio, L., Collatz, G. J., Mu, M., Kasibhatla, P. S., Morton, D. C., DeFries, R. S., Jin, Y., and van Leeuwen, T. T.: Global fire emissions and the contribution of deforestation, savanna, forest, agricultural, and peat fires (19972009), Atmos. Chem. Phys., 10, 11707-11735, doi:10.5194/acp5110-11707-12010, 2010.

Vingarzan, R.: A review of surface ozone background levels and trends, Atmos. Environ., 38, 3431-3442, 2004.
Wang, H., Jacob, D. J., Le Sager, P., Streets, D. G., Park, R. J., Gilliland, A. B., and Van Donkelaar, A.: Surface ozone background in the United States: Canadian and Mexican pollution influences, Atmos. Environ., 43, 1310-1319, 2009.

Wang, Y. and Jacob, D. J.: Anthropogenic forcing on tropospheric ozone and $\mathrm{OH}$ since preindustrial times, J. Geophys. Res. Atmos., 103, 31123-31135, 1998

Wang, Y., Jacob, D. J., and Logan, J. A.: Global simulation of tropospheric $\mathrm{O}_{3}-\mathrm{NO}_{\mathrm{x}}$-hydrocarbon chemistry. 1. Model formulation, J. Geophys. Res., 156, 148-227, 1998.

Wu, S., Mickley, L. J., Jacob, D. J., Logan, J. A., Yantosca, R. M., and Rind, D.: Why are there large differences between models in global budgets of tropospheric ozone?, J. Geophys. Res., 112, D05302, doi:10.01029/02006JD007801, 2007.

Wu, S., Mickley, L. J., Jacob, D. J., Rind, D., and Streets, D G.: Effects of 2000-2050 changes in climate and emissions on global tropospheric ozone and the policy-relevant background surface ozone in the United States, J. Geophys. Res. Atmos., 113, D18312, doi:10.1029/2007JD009639, 2008a

Wu, S., Mickley, L. J., Leibensperger, E. M., Jacob, D. J., Rind, D. and Streets, D. G.: Effects of 2000-2050 global change on ozone air quality in the United States, J. Geophys. Res., 113, D06302, doi:10.01029/02007JD009639, 2008b.

Wu, S., Mickley, L. J., Kaplan, J. O., and Jacob, D. J.: Impacts of changes in land use and land cover on atmospheric chemistry and air quality over the 21 st century, Atmos. Chem. Phys., 12, 15971609, doi:10.5194/acp-12-1597-2012, 2012.

Yu, F., Luo, G., Bates, T. S., Anderson, B., Clarke, A., Kapustin, V., Yantosca, R. M., Wang, Y., and Wu, S.: Spatial distributions of particle number concentrations in the global troposphere: Simulations, observations, and implications for nucleation mechanisms, J. Geophys. Res., 115, D17205, doi:10.1029/2009JD013473, 2010

Yurganov, L. N., McMillan, W. W., Dzhola, A. V., Grechko, E. I., Jones, N. B., and van der Werf, G. R.: Global AIRS and MOPITT $\mathrm{CO}$ measurements: Validation, comparison, and links to biomass burning variations and carbon cycle, J. Geophys. Res. Atmos., 113, D09301, doi:10.1029/2007JD009229, 2008

Zhang, L., Jacob, D. J., Liu, X., Logan, J. A., Chance, K., Eldering, A., and Bojkov, B. R.: Intercomparison methods for satellite measurements of atmospheric composition: application to tropospheric ozone from TES and OMI, Atmos. Chem. Phys., 10, 4725-4739, doi:10.5194/acp-4710-4725-2010, 2010.

Zhang, L., Jacob, D. J., Boersma, K., Jaffe, D., Olson, J., Bowman, K., Worden, J., Thompson, A., Avery, M., and Cohen, R.: Transpacific transport of ozone pollution and the effect of recent Asian emission increases on air quality in North America: an integrated analysis using satellite, aircraft, ozonesonde, and surface observations, Atmos. Chem. Phys., 8, 6117-6136, 2008, http://www.atmos-chem-phys.net/8/6117/2008/.

Zhang, Q., Streets, D. G., Carmichael, G. R., He, K. B., Huo, H., Kannari, A., Klimont, Z., Park, I. S., Reddy, S., Fu, J. S., Chen, D., Duan, L., Lei, Y., Wang, L. T., and Yao, Z. L.: Asian emissions in 2006 for the NASA INTEX-B mission, Atmos. Chem. Phys., 9, 5131-5153, doi:10.5194/acp-9-5131-2009, 2009. 